\title{
Pericardial Processing: Challenges, Outcomes and Future Prospects
}

\author{
Escande Rémi ${ }^{1,3}$, Nizar Khelil ${ }^{1}$, Isabelle Di Centa ${ }^{2}$, Caroline Roques ${ }^{1}$, \\ Maguette Ba ${ }^{1,3}$, Fatima Medjahed-Hamidi ${ }^{1}$, Frederic Chaubet ${ }^{1,3}$, \\ Didier Letourneur ${ }^{1,3}$, Emmanuel Lansac ${ }^{1,4}$ and Anne Meddahi-Pellé1,3
}

\section{Introduction}

The pericardium is a biological tissue widely used as a biomaterial for tissue engineering applications, including the construction of a variety of bioprostheses such as vascular grafts, patches for abdominal or vaginal wall reparation and, more frequently, heart valves.

However, despite significant advances, some drawbacks have been found in these bioprostheses such as biological matrix deterioration and tissue degeneration associated with calcifications, even though xenopericardium or glutaraldehyde-treated autologous pericardium were used.

In non-autologous pericardial processing, the pericardium must be decellularized in order to remove cellular antigens and procalcific remnants while preserving extracellular matrix integrity. A large variety of decellularization protocols exist, such as chemical, physical or enzymatic methods. Additional cross-linking processing must be carried out to render the tissue non-antigenic and mechanically strong.

So far, almost all bioprosthetic materials made of pericardium, and used in clinical practice, are glutaraldehyde-treated bovine or porcine xenopericardium. However, long-term reports are raising issues concerning their durability, especially highlighting the high risk of calcification. Regarding heart valves, calcification currently represents the major drawback leading to potential failure of the bioprosthesis.

The aim of this review is to present current issues, challenges, outcomes and future prospects of pericardial processing, including decellularization and cross-linking steps. Understanding current issues and improving pericardial processing will allow refining bioprosthesis conception and patients' safety.

\section{Characteristics of the pericardium}

\subsection{Localization and composition}

The pericardium is a connective tissue sac surrounding the heart. It is composed by two layers: a deeper layer closely adherent to the heart, the visceral serous pericardium, or

\footnotetext{
${ }^{1}$ Inserm U698, Bioengineering for Cardiovascular Imaging and Therapy Team, CHU Xavier Bichat, Paris

${ }^{2}$ Ambroise Paré Hospital, vascular surgery department, Boulogne,

${ }^{3}$ Bioengineering for cardiovascular imaging and therapy, Galilée Institut, Paris 13 University

${ }^{4}$ Montsouris Institut, Cardiovascular surgery department, Paris

1,2,3,4France
} 
epicardium, and an upper layer: the parietal pericardium. The two layers are separated by the pericardial cavity. The parietal pericardium can be excised and easily tested without causing major complications such as contracture or ischemia (Fomovsky et al., 2010).

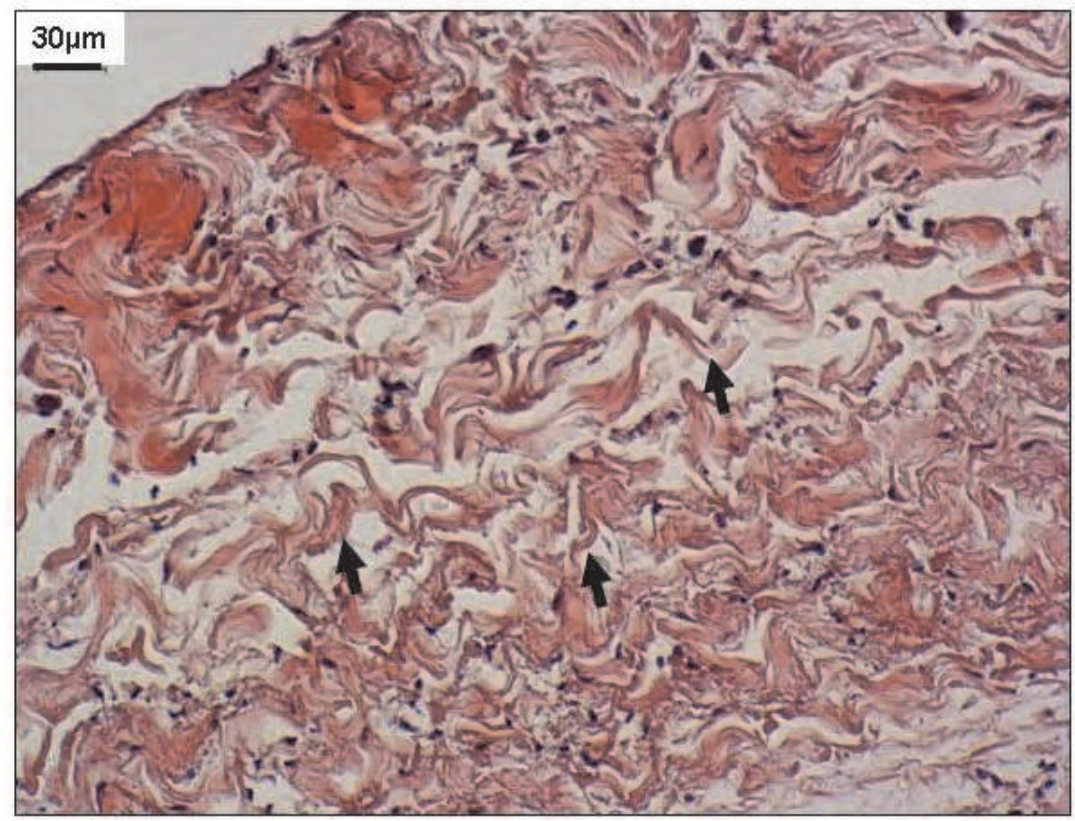

Fig. 1. Histology of ovine pericardium showing the collagen organization (arrows). Hematoxylin-Eosin staining.

The pericardium is composed of a simple squamous epithelium and connective tissue. It is a collagen-rich biological tissue containing mostly type I collagen, as well as glycoproteins and glycosaminoglycans (GAGs) in addition to its constitutive cells (Figure 1). Collagen is structured into different levels of organization ranging from fibrils to laminates, fibers and fiber bundles (Allen \& Didio, 1984; Lee \& Boughner, 1981). This organization determines the mechanical properties of the pericardial tissue (Sacks, 2003; Liao et al., 2005; Wiegner \& Bing, 1981; Lee \& Boughner, 1985) and provides an anisotropic and non-linear mechanical behaviour (Zioupos \& Barbenel, 1994). Interestingly, depending on the location on the pericardium, the thickness and mechanical properties vary (Hiester \& Sacks 1998a, 1998b). Thus, the location of the sample that will be harvested should be carefully selected when designing a tissue engineering protocol.

\subsection{Sources of pericardium}

Currently marketed heart valve bioprostheses are prepared from bovine or porcine pericardium (Vesely, 2005). Other pericardial tissues from different species have been assessed or are currently used in clinical practice such as equine (DeCarbo et al., 2010; Yamamoto et al., 2009; Sato et al.; 2008.), canine (Lee \& Boughner ; 1981; Wiegner \& Bing, 
1981; 1985), or, even more unusually, ostrich (Maestro et al., 2006) or kangaroo pericardium (Neethling et al., 2000; 2002). However, those exogenous grafts raise several issues, and especially the immune response against the bioprosthesis as well as the viral status of the graft.

Human autologous pericardium is thus an interesting option, presenting several advantages over allografts since it is free of donor-derived pathogens and does not induce any immune response (Mirsadraee et al., 2007), is easily available, easily handled and of low cost. Ultimately, these characteristics allow for shorter and less aggressive pericardial processing before implantation of the bioprosthesis. However, because of intermittent reports of its tendency to retract or become aneurysmal, the general opinion has been negative (Edwards et al., 1969, Bahnson et al., 1970). For cusp tissue replacement or valve tissue replacement, stabilization of pericardium is performed with a solution of $0,2 \%$ to $0,6 \%$ glutaraldehyde in order to prevent secondary shrinkage (Duran et al., 1998; Al-Halees et al., 1998, 2005; Goetz et al., 2002).

\section{Processing of pericardium}

As allografts have been the main source for pericardial bioprostheses currently in use, significant processing steps have to be performed prior to clinical use. In particular, as xenogeneic cellular antigens induce an immune response or an immune-mediated rejection of the tissue, decellularization protocols are widely used to reduce the host tissue response (Gilbert et al., 2006.). Once decellularized, the free-cell pericardial tissue is composed of extracellular matrix proteins which are generally conserved among species, and thus can be easily used as a scaffold for the host cell attachment, migration and proliferation (Schmidt \& Baier, 2000). This scaffold considerably accelerates tissue regeneration. Overall, tissue decellularization aims at reducing tissue antigenicity and host response while preserving the mechanical integrity, biological activity and composition of the ECM (Simon et al., 2006; Gilbert et al., 2006).

\subsection{Extracellular matrix decellularization methods}

Most decellularization protocols include a combination of various methods, such as physical, enzymatic or chemical treatments (Gilbert et al., 2006; Crapo et al., 2011). Physical methods can either rely on snap freezing (Jackson et al., 1988; Roberts et al., 1991), mechanical force (Freytes et al., 2004) or mechanical agitation (Schenke-Layland et al., 2003), whereas enzymatic protocols employ nucleases, calcium chelating agents or protease digestion (Teebken et al., 2000; Bader et al., 1998; McFetridge et al., 2004; Gamba et al., 2002). Regarding physical decellularization processes, sonication, based on the use of ultrasounds to disrupt the cell membrane, has been investigated. Such treatment considerably affects the pericardial architecture and full decellularization cannot be achieved. Thus sonication has to be carried out simultaneously with chemical treatments in order to fully decellularize the pericardial tissue and remove cellular debris. However, this combination leads to alterations of the extracellular matrix (ECM) architecture.

For the enzymatic procedure, the main enzyme employed is trypsin, cleaving peptide bonds on the C-side of arginine and lysine and thus allowing separation of the cells from the ECM.

Chemical protocols involve use of alkaline and acid treatments (Freytes et al., 2004), ionic detergents, sodium dodecyl sulfate (SDS), sodium deoxycholate and Triton X-200 (Rieder et 
al. 2004; Hudson et al., 2004), non-ionic detergents, such as Triton X-100 (Grauss et al., 2003), zwitterionic detergents (Dahl et al., 2003), tri(n-butyl)phosphate (Woods \& Gratzer, 2005) as well as hypertonic or hypotonic solutions (Goissis et al., 2000; Woods \& Gratzer, 2005; Vyavahareet al., 1997; Dahl et al., 2003). These modalities will either mediate lysis of the cells or solubilization of the cellular components.

Overall, standard decellularization protocols for allografts consist of a multimodal process starting with the lysis of the cell membrane using either ionic solutions or physical treatments. This initial step is then followed by enzymatic treatments to separate any cellular components from the ECM. Subsequently, detergents are used to solubilize the nuclear and cytoplasmic cellular components. At the end of the procedure, all residual cell debris is removed from the remaining ECM. A washing step must also be carried out following the decellularization protocol to remove residual chemicals, thus avoiding any host tissue response (Gilbert et al., 2006). The efficiency of the decellularization protocol and the preservation of the ECM have to be assessed using histological tools.

Concerning pericardial decellularization, several protocols, which have provided interesting results, can be found in the literature. (Courtman et al., 2004; Liang et al., 2004; Wei et al., 2005; Chang et al., 2005; Mendoza-Novelo et al., 2010, Ariganello et al., 2011 ). Courtman et al. proposed the use of a non-ionic detergent, Triton X-100 and an enzymatic extraction process. After this treatment, the acellular matrix was shown to be composed of collagen, elastin and glycosaminoglycans (GAG). Microscopy revealed that all cellular components were removed and that matrix ultrastructure was intact. More recently, Mendoza-Novelo et al. compared the surfactant tridecyl alcohol ethoxylate (ATE) and the reversible alkaline swelling (RAS) treatments to Triton X-100 (Mendoza-Novelo et al., 2010). Histological results indicated a significant reduction of cellular antigens with these three decellularization processes. Nevertheless, the native GAG content varied significantly. It decreased from $88.6 \pm 0.2 \%$ to $62.7 \pm 1.1 \%$ and $61.6 \pm 0.6 \%$ for RAS treatment, ATE and Triton X-100 respectively.

On human pericardial tissue, Mirsadraee $e t$ al. used a protocol employing hypotonic buffer, SDS, protease inhibitors and nuclease solution. Following decellularization, the tissue is decontaminated using a peracetic acid solution (Mirsadraee et al., 2006; 2007). With this process, glycosaminoglycans and structural proteins, such as collagen, remained intact.

Finally, when dealing with autologous pericardium grafting, full decellularization might not be necessary and thus, simpler protocols can be used. For instance, surgeons commonly prepare autologous pericardium for heart valve replacement by mechanical friction. This allows removing sub-pericardial fat before implantation while better preserving the pericardial architecture stability. This mechanical treatment mainly removes superficial cells, thus allowing $50 \%$ of viable pericardial cells to remain in the graft (personal data). The preservation of the pericardial architecture as well as part of the pericardial cells, should maintain a better integrity of the graft, while allowing re-cellularization of the superficial layers.

\subsection{Effects of decellularization}

Depending on the protocol, decellularization may have an impact on the structural and mechanical properties of the treated tissue (Gilbert et al., 2006). According to Zhou et al., decellularization protocols differ significantly in terms of alteration of ECM histoarchitecture (Zhou et al., 2010). For instance, decellularization protocols have a strong impact on the amount of GAGs remaining in a tissue (Badylak et al., 2009; Mendoza-Novelo et al., 2010). Removing GAGs from a tissue leads to adverse effects on pericardial 
viscoelastic properties. This can be easily understood since water retention is an important function of GAGs in tissues (Lovekamp et al., 2006). Moreover, GAG content plays a key biological role in cellular signaling and communication. Thus, decreasing GAG content leads to an impaired tissue response and repair. Therefore, the decellularization protocol has to be carefully chosen depending on the tissue type as well as the targeted application. Ideally, the process should remove all cellular antigens without compromising the structure and mechanical properties of the tissue.

Liao et al. (Liao et al., 2008) investigated the effect of three decellularization protocols on the mechanical and structural properties on porcine aortic valve leaflets. These protocols were based on the use of SDS, Trypsin and Triton X-100. They showed that decellularization resulted in collagen network disruption, and that the ECM pore size varied as a function of the protocol used. For example, leaflets treated with SDS displayed a dense ECM network and small pore sizes, characteristics that may have an impact on the recolonization of interstitial cells.

It has been demonstrated that decellularization of bovine pericardium with SDS causes irreversible denaturation, swelling and a decrease in tensile strength compared to native tissue (Courtman et al. 1994; García-Paéz et al., 2000; Mendoza-Novelo et al., 2009). Because of these deleterious effects on pericardial tissue, non-ionic detergents are preferred for decellularization processes (Mendoza-Novelo et al., 2010 ). Nevertheless, some issues may be encountered with the use of non-ionic detergents. Indeed, toxic effects (Argese et al., 1994) and estrogenic effects (Soto et al., 1991; Jobling et al., 1993) have been reported after the use of non-ionic detergents such as alkylphenol ethoxylates.

Decellularization mediates alterations of the structural and mechanical properties of the tissue, but this impact varies depending on the protocol used. For instance, Mirsadraee et al. (Mirsadraee et al., 2006) did not observe any significant changes using an SDS-based decellularization protocol in the ultimate tensile strength compared to native tissue on human pericardial tissue. They also observed an increased extensibility of the tissue when cut parallel to collagen bundles.

Tissue decellularization reduces the cellular and humoral immune response targeted against the bioprosthesis (Meyer et al., 2005). However, removing cells does not ensure adequate removal of xenoantigens, nor mitigation of the immune response (Goncalves et al., 2005; Kasimir et al., 2006; Simon et al., 2003; Vesely et al., 1995). For this reason, decellularization protocols have turned to antigen removal protocols (Ueda et al., 2006; Kasimir et al., 2005). The presence of cell membrane antigens, such as oligosaccharide beta-Gal has been reported to lead to an immune response that can be prevented by effective decellularization (Badylak et al., 2008). Interestingly, Griffiths et al. (Griffiths et al., 2008) used an immunoproteomic approach to study the ability of bovine pericardium to generate a humoral immune response. They identified thirty one putative protein antigens. Some of them, such as albumin, hemoglobin chain A and beta hemoglobin have been identified as xenoantigens. Recently, Ariganello et al. provided evidence that decellularized bovine pericardium induced less differentiation of the monocytes to macrophages compared to polydimethylsiloxane or polystyrene surfaces (Ariganello et al., 2010; 2011). Nevertheless, the effects of the host immune response to acellular pericardium remain to be fully characterized. Understanding this phenomenon is necessary to develop new pericardium preparations and thus improve biological scaffold integration and clinical safety (Badylak \& Gilbert, 2008).

Overall, no optimal decellularization treatment has been identified so far, but depending on the target tissue as well as the implantation site, the protocol can be adapted to provide the 
best decellularization efficiency / functional characteristics ratio. Moreover, some additional treatment can be performed following the decellularization step in order to improve the mechanical and biological features of the graft.

\section{Pericardial extracellular matrix treatment}

The decellularization process will lead to important alterations of the biomaterial. Its mechanical strength will be diminished and after implantation it will undergo rapid resorption. Hence, approximately $60 \%$ of the mass of the ECM is degraded and resorbed between one and three months after in vivo grafting (Badylak \& Gilbert, 2008). It has also been noted that acellular pericardial tissue, mostly made of type I collagen, is highly thrombogenic (Keuren et al., 2004). Finally, preventing calcification of the graft is also a priority to ensure the long-term benefit of the implantation.

To optimize the features of the bioprosthesis before its clinical grafting, several treatments have been developed and are summarized in Table 1.

\begin{tabular}{|c|c|c|}
\hline & Reagents & References \\
\hline $\begin{array}{l}\text { Cross-linking } \\
\text { treatment }\end{array}$ & $\begin{array}{l}\text { Acyl azide } \\
\text { Carbodiimides } \\
\text { Cyanimide } \\
\text { Dye-mediated photooxidation } \\
\text { Epoxy compound } \\
\text { Formaldehyde } \\
\text { Genepin } \\
\text { Glutaraldehyde } \\
\text { Glutaraldehyde acetals } \\
\text { Penta-golloyl glucose } \\
\text { Phytate } \\
\text { Proanthocyanidin } \\
\text { Reuterin } \\
\text { Tannic acid }\end{array}$ & $\begin{array}{l}\text { (Petite et al., 1990) } \\
\text { (Sung et al., 2003) } \\
\text { (Pereira et al., 1990) } \\
\text { (Moore et al., 1994) } \\
\text { (Sung et al., 1997) } \\
\text { (Nimni et al, 1988) } \\
\text { (Sung et al., 1999, 2003; Wei et al., 2005) } \\
\text { (Huang-Lee et al, 1990; Jayakrishnan et al., } \\
\text { 1996; Thubrikar et al., 1983) } \\
\text { (Yoshioka et al., 2008) } \\
\text { (Tedder et al., 2008) } \\
\text { (Grases et al., 2006, 2008) } \\
\text { (Han et al., 2003) } \\
\text { (Chen et al., 2002) } \\
\text { (Cwalina et al., 2005; Jastrzebska et al., 2006; } \\
\text { Wang et al., 2008) } \\
\end{array}$ \\
\hline $\begin{array}{l}\text { Coating } \\
\text { treatment }\end{array}$ & $\begin{array}{l}\text { Chitosan } \\
\text { RGD polypeptides } \\
\text { Silk fibroin } \\
\text { Heparin sodium } \\
\text { Titanium } \\
\end{array}$ & $\begin{array}{l}\text { (Nogueira et al., 2010) } \\
\text { (Dong et al., 2009) } \\
\text { (Nogueira et al., 2010) } \\
\text { (Lee et al., 2000) } \\
\text { (Guldner et al., 2009) } \\
\end{array}$ \\
\hline $\begin{array}{l}\text { Post-fixative } \\
\text { treatment }\end{array}$ & $\begin{array}{l}\text { Amino acids } \\
\text { Glycine } \\
\text { Heparin } \\
\text { Hyaluronic acid } \\
\text { L-arginine } \\
\text { L-glutamic } \\
\text { Lyophilization } \\
\text { Sulphonated poly(ethylene oxide) } \\
\end{array}$ & $\begin{array}{l}\text { (Jorge-Herrero et al., 1996; } \\
\text { Moritz et al., 1991) } \\
\text { (Lee et al., 2010) } \\
\text { (Lee et al., 2000, 2001) } \\
\text { (Ohri et al., 2004) } \\
\text { (Jee et al., 2003) } \\
\text { (Grimm et al., 1991; Leukauf et al., 1993) } \\
\text { (Santibáñez-Salgado et al., 2010) } \\
\text { (Lee et al., 2001) }\end{array}$ \\
\hline
\end{tabular}

Table 1. Pericardial processing. 


\subsection{Cross-linking treatment of pericardial tissue}

Cross-linking processing must be carried out to render the tissue non-antigenic, mechanically strong and to minimize xenogeneic tissue degradation (Eliezer et al., 2005; Love, 1997). Nevertheless, degradation should not only be considered as a negative phenomenon, as low molecular weight peptides formed during ECM degradation may have a chemo-attractant potential for several cell types (Badylak \& Gilbert, 2008). It is thus the degradation rate of the scaffold that should be primarily considered and evaluated. Depending on the application and cells involved, the degradation rate has to be investigated to ensure proper host cell recruitment and tissue remodelling. The pathways of the immune response involved in this process remain to be fully described (Badylak \& Gilbert, 2008).

Introducing cross-links between the polypeptide chains of the ECM has been shown to reduce immunogenicity of the pericardium (Mirsadrae et al., 2007) as well as its biodegradability (Taylor et al., 2006) by increasing its resistance to enzymatic degradation. Until now, glutaraldehyde (GA)-fixed bovine pericardium has been preferred as a substitute to autologous human pericardium. GA was first introduced by Carpentier et al. (Carpentier et al., 1969) as a cross-linking reagent to chemically modify the collagen and render the tissue immunologically acceptable in the human host. Fixation was shown to increase stability and strength of the pericardium (Jayakrishnan \& Jameela, 1996). GA remains the gold standard as a cross-linking reagent despite its well-known drawbacks. Indeed, GA has been reported to accelerate the calcification process, which considerably limits its application. Calcification is thus the main cause of long-term failure of GA-fixed pericardial valves (Gallo et al., 1985; Grabenwoger et al., 1996). Furthermore, a GA-treated pericardium has a poor ability to regenerate in vivo due to the cross-linking of the tissue. Moreover GA residues display cytotoxic effects preventing host cell attachment, migration and proliferation (Huang-Lee et al., 1990).

It is now accepted that GA cross-linking increases tissue stiffness (Thubrikar et al., 1983) with the possibility of tissue buckling (Vesely et al., 1988). Standard use of GA cross-linking leads to a high risk of calcific degeneration as well as tissue fatigue (Grabenwoger et al., 1992). This is mostly due to inflammatory and cytotoxicity changes (Huang Lee et al., 1990), and continuous wear and tear leading to collagen fiber fragmentation.

Besides glutaraldehyde, several cross-linking compounds have been reported in the literature such as genipin (Wei et al., 2005) or epoxy compound (Sung et al., 1997). These alternative methods are used to bridge hydroxylysine residues of different polypeptide chains or amino groups of lysine by oligomeric or monomeric crosslinks (Sung et al., 2003). Because of the adverse effects of cross-linking with glutaraldehyde or other aldehyde treatments such as formaldehyde (Nimni et al., 1988) or dialdehyde starch (Rosenberg, 1978), numerous non-aldehyde treatments have been proposed, such as carbodiimides (Sung et al., 2003), glycerol (Ferrans et al., 1991), glycidal ethers (Thyagarajanet al., 1992) including poly(glycidylether) (Noishiki et al., 1986), acyl azide (Petite et al., 1990), cyanimide (Pereira et al., 1990), genipin (Wei et al., 2005), or dye-mediated photo-oxidation, phytate (Grases et al., 2008).

Genipin, obtained from the fruits of Gardenia jasminoides ELLIS (Fujikawa et al., 1987; Tsai et al., 1994), exhibited better results than glutaraldehyde regarding its cytotoxicity (Sung et al., 1999), inflammatory response, ability to prevent calcification and tissue-induced mechanical properties (Wei et al., 2005). Epoxy compound, initially proposed by Noishiki et al. (Noishiki 
et al., 1989), was shown to be less cytotoxic, superior in pliability and to better inhibit calcification than glutaraldehyde (Sung et al., 1997).

Carbodiimides generate amide-type crosslinks via direct cross-linking of the polypeptide chains. Use of carbodiimide cross-linking leads to the activation of the carboxylic acid groups of glutamic or aspartic acid residues to obtain O-acylisourea groups. Hydroxyline residues or free amino groups of lysine generate a nucleophilic attack which allows crosslink formation (Timkovich, 1977). It was noted that adding N-hydroxysuccinimides to carbodiimides considerably increases cross-link number (Olde Damink et al., 1996). In addition, the use of carbodiimides displayed increased stability towards enzymatic degradation on collagen-based tissue such as pericardium (Sung et al., 2003).

Glutaraldehyde acetal cross-linking reagent has been developed with glutaraldehyde in acid ethanolic solution (Yoshioka \& Goissis, 2008), protecting free aldehydic reactive groups and minimizing the polymeric formation of glutaraldehyde. This reduces superficial effects with glutaraldehyde cross-linking on pericardial tissue.

Crosslinking of the pericardial tissue with a dye-mediated photo-oxydation process provides chemical, enzymatic and in vivo stability as well as biomechanical integrity of the treated tissue (Moore et al., 1994). Penta-golloyl glucose, a collagen-binding polyphenol, stabilizes collagen, preventing its degradation, and allows progressive host cell infiltration as well as ECM remodeling. An in vivo study has shown that porcine pericardium does not calcify with such treatment at 6 weeks when implanted subdermally in rats (Tedder et al., 2008). Reuterin, an antimicotic and antibacterial compound obtained from Lactobacillus reuteri (Axelsson et al., 1989), has been studied as a crosslinking reagent (Chen et al., 2002). It is a three-carbon aldehyde reacting, as formaldehyde, with free amino groups. Reuterin cross-linked pericardium exhibits comparable results to glutaraldehyde in terms of resistance against enzymatic degradation, denaturation temperature and free amino group content, while decreasing cytotoxic effects (Chen et al., 2002). Tannic acid has been studied on pericardial tissue and was shown to crosslink proteins by creating multiple hydrogen bonds due to its hydroxyl groups (Cwalina et al., 2005; Jastrzebska et al., 2006). It exerts an anti-inflammatory effect, especially on macrophages, as well as an anti-calcification effect on glutaraldehyde-fixed bovine pericardium (Wang et al., 2008). Proanthocyanidin, a natural crosslinking reagent with polyphenolic structures, has the potential to create a stable hydrogen-bonded structure and to increase collagen synthesis, generating nonbiodegradable collagen matrices (Han et al., 2003). Proanthocyanidin-treated pericardial tissues are non-cytotoxic and resist against enzyme digestion, and have been shown to be compatible with cell attachment and proliferation. Phytate has been suggested as an anticalcification reagent (Grases et al., 2006, 2008) and has achieved promising results, to be validated by further studies. Other amide-type crosslinks, based on the activation of carboxyl groups, have been studied, such as diphenylphosphorylazide or ethyldimethylaminopropyl carbodiimide. It appears, according to Jorge-Herrero et al., that these two chemical treatments are not a good alternative compared to glutaraldehyde. Indeed, pericardial tissues treated with those reagents are less resistant to calcifications and proteolytic attacks (Jorge-Herrero et al., 1999).

Numerous alternative treatments to glutaraldehyde cross-linking have been developed and investigated over the years. However, most of them were mainly evaluated in vitro and compared only to glutaraldehyde. A comprehensive comparative study of the different reagents remains to be conducted in terms of benefits regarding the tissue properties as well as their potential toxicity or deleterious effects. 


\subsection{Coating of the pericardium}

Another possible post-decellularization treatment resides in the coating of the bioprosthesis. This procedure should allow improvement of graft integration at the site of implantation as well as decreasing degradation of the pericardial tissue.

Coating bovine pericardium with biopolymeric films, either chitosan or silk fibroin, has been investigated by Nogueira et al. (Nogueira et al., 2010). These methods are interesting approaches and both treatments appear to be non-cytotoxic. Nevertheless, chitosan does not allow endothelialisation and silk fibroin-coated bovine pericardium calcifies in vivo. Further investigation has to be performed to tackle these major concerns.

In their study, Dong et al. suggested treating bovine pericardium with acetic acid coupled with RGD polypeptides (Dong et al., 2009). Acetic acid increases pericardial scaffold pore size and porosity while RGD peptides is meant to improve cell adhesion and growth. Hence, RGD polypeptides have been identified in fibronectin (Pierschbacher \& Ruoslahti, 1984), collagen, vitronectin and membrane proteins (Ruoslahti \& Pierschbacher, 1987). These sequences have an impact on integrins, which display cell adhesion receptor roles controlling cell signaling pathways.

\subsection{Pericardium anti-calcification treatments}

The mechanism of calcification on glutaraldehyde-treated pericardium is not well understood because of its complexity. Nevertheless, there is evidence that pericardial tissue residual antigens, free aldhehyde groups of glutaraldehyde and phospholipids are involved in this mechanism.

Thus, circulating antibodies can contribute to pericardial calcification due to a possible immune response. Free aldehyde groups of glutaraldehyde can attract host plasma calcium, increasing tissue calcification. Phospholipids may bind calcium and play an important role in the calcium phosphate crystal formation. Several strategies have been investigated to tackle these major issues.

Suppression of residual antigenicity has been proposed to prevent calcification and it has been shown to be effective. This was performed by fixation treatments using a broad range of high concentrations of glutaraldehyde (Trantina-Yates et al., 2003; Zilla et al., 2000). To remove free aldehyde groups, a large number of amino acids or amino compounds were studied. Post-fixation treatments with amino acids displayed an improved spontaneous endothelialisation in vivo of glutaraldehyde-fixed bovine pericardium (Moritz et al., 1991; Jorge-Herrero et al., 1996). The use of L-glutamic acid did reduce residual and unbound aldehyde groups, on glutaraldehyde-fixed bovine pericardium and significantly decreased the risk of calcification (Grimm et al., 1991; Leukauf et al., 1993). Post-treatment with Larginine also resulted in decreased calcium deposition (Jee et al., 2003). Recently, Lee et al. proposed a post-fixation treatment with glycine (Lee et al., 2010). Early results are promising but require further investigation on larger studies.

Alcohol solutions, including ethanol, have been investigated as a treatment to remove tissue phospholipids, thus preventing calcification (Pathak et al., 2004; Vyavahare et al., 1998). Besides, other techniques have been proposed to minimize the side effects of glutaraldehyde residues on GA-treated pericardium. Lyophilization has been shown to decrease aldehyde residues, decreasing the risk of calcification and cytotoxicity (Santibáñez-Salgado et al., 2010). Moreover, treatments with heparin or sulphonated poly(ethylene oxide) following glutaraldehyde pre-treatment have been proposed (Lee et al., 2000, 2001). Both methods block side effects of GA residues and thus prevent calcification of the pericardium. Finally, a 
modified adipic dihydrazide hyaluronic acid has been proposed to be grafted on to glutaraldehyde-treated bovine pericardium (Ohri et al., 2004). Calcifications decreased considerably with this post-treatment compared to the control group at two weeks following a subcutaneous implantation in mice.

\section{Applications of the pericardium as a biomaterial}

So far, the pericardium has been mostly used for cardio-vascular applications, i.e. vascular grafts (Schmidt \& Baier, 2000; Chvapil et al., 1970; Matsagas et al., 2006; Menasche et al.,

\begin{tabular}{|c|c|c|c|}
\hline $\begin{array}{l}\text { Pericardium } \\
\text { source }\end{array}$ & Surgical fields & Product & Company \\
\hline \multirow{7}{*}{$\begin{array}{l}\text { Bovine or } \\
\text { porcine }\end{array}$} & $\begin{array}{l}\text { Soft tissue repair } \\
\text { Hernia repair } \\
\text { Abdominal \& thoracic } \\
\text { wall defects }\end{array}$ & $\begin{array}{l}\text {-Peripatch } ® \text { Implantable } \\
\text { surgical tissue } \\
\text {-TutoMesh } ®\end{array}$ & $\begin{array}{l}\text { Neovasc, } \\
\text { Maverick Biosciences PTY Limited, } \\
\text { Tutogen medical GmbH, RTI Biologics, } \\
\text { Med\&Care, } \\
\text { Biovascular Inc, } \\
\text { Novomedics }\end{array}$ \\
\hline & Strip reinforcement & -Veritas Peristrips ${ }^{\circledR}$ Dry & Synovis Life Technology \\
\hline & Orbital repair & $\begin{array}{l}\text {-Tutopatch }{ }^{\circledR} \\
\text {-Ocugard }{ }^{\circledR}\end{array}$ & $\begin{array}{l}\text { Tutogen medical GmbH, RTI Biologics, } \\
\text { Med\&Care, } \\
\text { Biovascular Inc, } \\
\text { Novomedics }\end{array}$ \\
\hline & Dural repair & -Lyolem ${ }^{\circledR}$ r All BP & National tissue Bank Malaysia \\
\hline & Perivascular Patch & $\begin{array}{l}\text {-Peripatch } \AA \text { biologic } \\
\text { vascular patch }\end{array}$ & Neovac \\
\hline & $\begin{array}{l}\text { Cardiac reconstruction } \\
\text { and repair }\end{array}$ & $\begin{array}{l}\text {-Peripatch }{ }^{\circledR} \text { Implantable } \\
\text { Surgical Tissue }\end{array}$ & $\begin{array}{l}\text { Neovasc, Maverick Biosciences PTY } \\
\text { Limited }\end{array}$ \\
\hline & $\begin{array}{l}\text { Heart valve } \\
\text { replacement }\end{array}$ & $\begin{array}{l}\text {-PercevalS® aortic valve } \\
\text {-Mitroflow }{ }^{\circledR} \text { pericardial } \\
\text { aortic valve } \\
\text {-Freedom solo }{ }^{\circledR} \\
\text {-Carpentier-Edwards } \\
\text { PERIMOUNT® Magna } \\
\text { EaseAortic Heart Valve } \\
\text {-Carpentier-Edwards } \\
\text { PERIMOUNT® Magna } \\
\text { Mitral Ease Heart Valve } \\
\text {-Carpentier-Edwards } \\
\text { PERIMOUNT® Theon } \\
\text { Aortic Heart Valve } \\
\text {-Carpentier-Edwards } \\
\text { PERIMOUNT® Theon } \\
\text { Mitral Replacement } \\
\text { System }\end{array}$ & $\begin{array}{l}\text { Sorin group } \\
\text { “" } \\
\text { Edwards Life Sciences }\end{array}$ \\
\hline Equine & Tendon repair & -OrthADAPT® & Synovis Life Technologies Inc \\
\hline Human & $\begin{array}{l}\text { Valvuloplasty } \\
\text { Heart valve }\end{array}$ & $\begin{array}{l}\text {-Xeno or (tissue bank) or } \\
\text { autologous grafts }\end{array}$ & $\begin{array}{l}\text { Lausberg et al, } 2006 \\
\text { Mirsadaee et al, } 2006\end{array}$ \\
\hline
\end{tabular}

Table 2. Applications of pericardium as medical devices. 
1984; Moon \& West; 2008), and heart valves (Ishihara et al., 1981; Schoen \& Levy, 1999; Flanagan \& Pandit, 2003; Vesely, 2005). Pericardial bioprostheses have also been described for the treatment of acquired cardiac pathologies, including postinfarction septal defects (David et al., 1995), reconstruction of mitral valve annulus (David et al., 1995a, 1995b) or outflow obstruction (Sommers \& David, 1997).

Additionally, pericardium has also been used for the construction of bioprostheses in noncardiac treatments such as patches for vaginal (Lazarou et al., 2005) or abdominal wall reparation (Limpert et al., 2009), dural repair (Cantore et al., 1987) or tracheoplasty (Dunham et al., 1994).

\section{Conclusion}

For clinical application, pericardial tissue has to be decellularized to prevent an immune responses or immune-mediated rejection of the pericardium. Various decellularization protocols have been largely reviewed here. The choice of the decellularization strategy has an impact on the mechanical properties, the scaffold pore size, the scaffold tissue integration and the development of long-term calcification. All these considerations should be carefully taken into account when designing new pericardial-based biomaterials. Currently, glutaraldehyde is the gold standard for pericardial treatment used in clinical practice. Nevertheless, it has important drawbacks including cytotoxic effects, prevention of host cell attachment, migration and proliferation (Huang-Lee et al., 1990), and a high propensity to calcify. Alternative treatments to replace or complement glutaraldehyde crosslinking of the pericardium have been investigated using other crosslinking reagents, decellularization, lyophilisation or coating with biopolymers (Nogueira et al., 2010). Despite many studies, it is still difficult to know which strategy to adopt regarding pericardial treatment. First, we do not have enough follow-up to permit evaluation of most of these alternatives and treatments. Second, every new treatment proposed is generally compared only to glutaraldehyde. It is thus not possible to classify these treatments by efficiency. Finally, the protocol for an optimal treatment depends largely on the final application targeted. In addition, there have been recent advances in tissue regeneration with the emergence of cell therapy and new pericardial treatments with cellular growth factors promoting recellularization (Chang et al., 2007). However, further improvements need to be achieved to transform these techniques into clinical applications. The use of autologous pericardium in cardiac valvular therapy is also a challenging alternative. Nevertheless, it still currently requires the development of local pericardial treatments aiming to favor the valvular remodelling. The understanding of current issues and the improvement of pericardial processing may have a huge impact for bioprothesis conception and patient safety.

\section{References}

Al-Halees Z, Gometza B, Duran CM. Aortic valve repair with bovine pericardium. (1998). Ann Thorac Surg, Vol. 65, pp. (601-602).

Al-Halees Z, Al Shahid M, Al Sanei A, Sallehuddin A, Duran C. Up to 16 years follow-up of aortic valve reconstruction with pericardium: a stentless readily available cheap valve? (2005) Eur J Cardiothorac Surg. Aug; Vol.28, pp.(200-205).

Allen DJ, Didio LJA. (1984). The structure of native human, bovine and porcine parietal pericardium. Anatomical Record, Vol. 208, No. 3, pp. (7A-7A). 
Argese E, Marcomini A, Bettiol C, Perin G, Miana P. (1994). Submitochondrial particle response to linear alkylbenzene sulfonates, nonylphenol polyethoxylates and their biodegradation derivates. Environ Toxicol Chem, Vol. 13, pp. (737-742).

Ariganello MB, Labow RS, Lee JM. (2010). In vitro response of monocyte-derived macrophages to a decellularized pericardial biomaterial. J Biomed Mater Res, Vol. 93, No. 1, pp. (280-288).

Ariganello MB, Simionescu DT, Labow RS, Lee JM. (2011). Macrophage differentiation and polarization on a decellularized pericardial biomaterial. Biomaterials, Vol. 32, No. 2, pp. (439-449).

Axelsson L, Chung TC, Dobrogosz WJ, Lindgren LE. (1989). Production of a broad spectrum antimicrobial substance by Lactobacillus reuteri. Microbial Ecol Health Disease, Vol. 2, pp. (131-136).

Bader A, Schilling T, Teebken OE, Brandes G, Herden T, Steinhoff G, Haverich A. (1998). Tissue engineering of heart valves - human endothelial cell seeding of detergent acellularized porcine valves. Eur J Cardiothorac Surg, Vol. 14, No. 3, pp. (279-284).

Badylak SF, Freytes DO, Gilbert TW. (2009). Extracellular matrix as a biological scaffold material: structure and function. Acta Biomater, Vol. 5, No. 1, pp. (1-13).

Badylak SF, Gilbert TW. (2008). Immune response to biologic scaffold materials. Seminars in Immunology, Vol. 20, No. 2, pp. (109-116).

Bahnson HT, Hardesty RL, Baker LD, Brookes D II, Gall DA. (1970) Fabrication and evaluation of tissue leaflets for aortic and mitral valve replacement. Ann Surg, Vol.171, pp. (939-947).

Cantore G, Guidetti B, Delfini R. (1987). Neurosurgical use of human dura mater sterilized by gamma rays and stored in alcohol: long-term results. J Neurosurg, Vol. 66, No. 1, pp. (93-95).

Carpentier A, Lemaigre G, Robert L, Carpentier S, Dubost C. (1969). Biological factors affecting long-term results in valvular heterografts. J Thorac Cardiovasc Surg, Vol. 58 , No. 4, pp. (467-483).

Chang Y, Chen SC, Wei HJ, Wu TJ, Liang HC, Lai PH, Yang HH, Sung HW. (2005). Tissue regeneration observed in a porous acellular bovine pericardium used to repair a myocardial defect in the right ventricle of a rat model. J Thorac Cardiovasc Surg, Vol. 130, No. 5, pp. (705-711).

Chang Y, Lai PH, Wei HJ, Lin WW, Chen CH, Hwang SM, Chen SC, Sung HW. (2007). Tissue regeneration observed in a basic fibroblast growth factor-loaded porous acellular bovine pericardium populated with mesenchymal stem cells. J Thorac Cardiovasc Surg, Vol. 134, No. 1, pp. (65-73).

Chen CN, Sung HW, Liang HF, Chang WH. (2002). Feasibility study using a natural compound (reuterin) produced by Lactobacillus reuteri in sterilizing and crosslinking biological tissues. J Biomed Mater Res, Vol. 61, No. 3, pp. (360-369).

Chvapil M, Kronenthal RL, van Winkle Jr W. (1970). Medical and surgical applications of collagen, In: International review of connective tissue research, Hall DA, Jackson DS. Vol. 6, pp. (1-61) [Chapter 1], Academic Press, NY.

Courtman DW, Pereira CA, Kashef V, McComb D, Lee JM, Wilson GJ. (1994). Development of a pericardial acellular matrix biomaterial: biochemical and mechanical effects of cell extraction. J Biomed Mater Res, Vol. 28, No. 6, pp. (655-666).

Crapo PM, Gilbert TW, Badylak SF. (2011). An overview of tissue and whole organ decellularization processes. Biomaterials, Vol. 32, No. 12, pp. (3233-3243). 
Cwalina B, Turek A, Nozynski J, Jastrzebska M, Nawrat Z. (2005). Structural changes in pericardium tissue modified with tannic acid. Int J Artif Organs, Vol. 28, No.6, pp. (648-653).

Dahl SL, Koh J, Prabhakar V, Niklason LE. (2003). Decellularized native and engineered arterial scaffolds for transplantation. Cell Transplant, Vol. 12, No. 6, pp. (659-666).

David TE, Dale L, Sun Z. (1995). Postinfarction ventricular septal rupture: Repair by endocardial patch with infarct exclusion. J Thorac Cardiovasc Surg, Vol. 110, No. 5, pp. (1315-1322).

David TE, Feindel CM, Armstrong S, et al. (1995). Reconstruction of the mitral annulus. A ten-year experience. J Thorac Cardiovas Surg, Vol. 110, pp. (1323-x1328).

DeCarbo WT, Feldner BM, Hyer CF. (2010). Inflammatory Reaction to Implanted Equine Pericardium Xenograft. J Foot Ankle Surg, Vol. 49, No. 2, pp. (155-158).

Dong X, Wei X, Yi W, Gu C, Kang X, Liu Y, Li Q, Yi D. (2009). RGD-modified acellular bovine pericardium as a bioprosthetic scaffold for tissue engineering. J Mater Sci Mater Med, Vol. 20, pp. (2327-2336).

Dunham ME, Holinger LD, Backer CL, Mavroudis C. (1994). Management of severe congenital tracheal stenosis. Ann Otol Rhinol Laryngol, Vol. 103, pp. (351-356).

Duran CM, Gometza B, Shahid M, Al-Halees Z. Treated bovine and autologous pericardium for aortic valve reconstruction. (1998) Ann Thorac Surg. Dec; Vol. 66, pp (S166-199).

Edwards WS. (1969). Aortic valve replacement with autogenous tissue. Ann Thorac Surg Vol. 8, pp. (126-32).

Eliezer MA, Lydia MM, Virna VR, Carlos FR. (2005). Mechanics of biomaterials: vascular graft prostheses. Proceedings of Application of Engineering Mechanics in Medicine, GED, University of Puerto Rico, Mayaguez, Group A: A1-A25, May 2005.

Ferrans VJ, Milei J, Ishihara T, Storino R. (1991). Structural changes in implanted cardiac valvular bioprostheses constructed of glycerol-treated dura mater. Eur J Cardiothorac Surg, Vol. 5, No. 3, pp. (144-154).

Flanagan TC, Pandit A. (2003). Living artificial heart valve alternatives: a review. Eur Cell Mater, Vol. 6, pp. (28-45).

Fomovsky GM, Thomopoulos S, Holmes JW. (2010). Contribution of extracellular matrix to the mechanical properties of the heart. J Mol Cell Cardiol, Vol. 48, No. 3, pp. (490496).

Freytes DO, Badylak SF, Webster TJ, Geddes LA, Rundell AE. (2004). Biaxial strength of multilaminated extracellular matrix scaffolds. Biomaterials, Vol. 25, No. 12, pp. (2353-2361).

Fujikawa S, Yokota T, Koga K, Kumada J. (1987). The continuous hydrolysis of geniposide to genipin using immobilized $\beta$-glucosidase on calcium alginate gel. J Biotechnol Lett, Vol. 9, pp. (697-702).

Gallo I, Artinano E, Nistal F. (1985). Four- to seven-year follow-up of patients undergoing Carpentier-Edwards porcine heart valve replacement. Thorac Cardiovasc Surg, Vol. 33, No. 6, pp. (347-351).

Gamba PG, Conconi MT, Lo Piccolo R, Zara G, Spinazzi R, Parnigotto PP. (2002). Experimental abdominal wall defect repaired with acellular matrix. Pediatr Surg Int, Vol. 18, No. 5-6, pp. (327-331).

García-Paéz JM, Herrero J, Carrera-San Martín A, García-Sestafe JV, Téllez G, Millán I, Salvador J, Cordon A, Castillo-Olivares JL. (2000). The influence of chemical 
treatment and suture on the elastic behavior of calf pericardium utilized in the construction of cardiac bioprostheses. J Mater Sci Mater Med, Vol. 11, No. 5, pp. (273-277).

Gilbert TW, Sellaro TL, Badylak SF. (2006). Decellularization of tissues and organs. Biomaterials, Vol. 27, No. 19, pp. (3675-3683).

Goetz WA, Lim HS, Lansac E, Weber PA, Duran CM. A temporarily stented, autologous pericardial aortic valve prosthesis. (2002) J Heart Valve Dis. Sep;11(5):(696-702).

Goissis G, Suzigan S, Parreira DR, Maniglia JV, Braile DM, Raymundo S. (2000). Preparation and characterization of collagen-elastin matrices from blood vessels intended as small diameter vascular grafts. Artif Organs, Vol. 24, No. 3, pp. (217-223).

Goncalves AC, Griffiths LG, Anthony RV, Orton EC. (2005). Decellularization of bovine pericardium for tissue-engineering by targeted removal of xenoantigens. J Heart Valve Dis, Vol. 14, No. 2, pp. (212-217).

Grabenwoger M, Grimm M, Eybl E, Leukauf C, Muller MM, Plenck Jr H, Böck P. (1992). Decreased tissue reaction to bioprosthetic heart valve material after glutamic acid treatment. A morphological study. J Biomed Mater Res, Vol. 26, No. 9, pp. (12311240).

Grabenwoger M, Sider J, Fitzal F, Zelenka C, Windberger U, Grimm M, Moritz A, Böck A, Wolner E. (1996). Impact of glutaraldehyde on calcification of pericardial bioprosthetic heart valve material. Ann Thorac Surg, Vol. 62, No. 3, pp. (772-777).

Grases F, Sanchis P, Costa-Bauzá A, Bonnin O, Isern B, Perelló J, Prieto RM. (2008). Phytate inhibits bovine pericardium calcification in vitro. Cardiovasc Pathol, Vol. 17, No. 3, pp. (139-145).

Grases F, Sanchis P, Perello J, Isern B, Prieto RM, Fernandez-Palomeque C, Fiol M, Bonnin O, Torres JJ. (2006). Phytate (myo-inositol hexakisphosphate) inhibits cardiovascular calcifications in rats. Front Biosci, Vol. 11, pp. (136-142).

Grauss RW, Hazekamp MG, van Vliet S, Gittenberger-de Groot AC, DeRuiter MC. (2003). Decellularization of rat aortic valve allografts reduces leaflet destruction and extracellular matrix remodeling. J Thorac Cardiovasc Surg, Vol. 126, No. 6, pp. (20032010).

Griffiths LG, Choe LH, Reardon KF, Dow SW, Orton EC. (2008). Immunoproteomic identification of bovine pericardium xenoantigens. Biomaterials, Vol. 29, No. 26, pp. (3514-3520).

Grimm M, Eybl E, Grabenwoger M, Griesmacher A, Losert U, Bock P, Muller MM, Wolner E. (1991). Biocompatibility of aldehyde-fixed bovine pericardium. An in vitro and in vivo approach toward improvement of bioprosthetic heart valves. I Thorac Cardiovasc Surg, Vol 102, No. 2, pp. (195-201).

Guldner NW, Jasmund I, Zimmermann H, Heinlein M, Girndt B, Meier V, Flüß F, Rohde D, Gebert A, Sievers HH. (2009). Detoxification and Endothelialization of Glutaraldehyde-Fixed Bovine Pericardium With Titanium Coating: A New Technology for Cardiovascular Tissue Engineering. Circulation, Vol. 119, No. 12, pp. (1653-1660).

Han B, Jaurequi J, Wei Tang B, Nimni ME. (2003). Proanthocyanidin: A natural crosslinking reagent for stabilizing collagen matrices. J Biomed Mater Res A, Vol. 65, No. 1, pp. (118-124). 
Hiester ED, Sacks MS. (1998a). Optimal bovine pericardial tissue selection sites. I. Fiber architecture and tissue thickness measurements. J Biomed Mater Res, Vol. 39, No. 2, pp. (207-214).

Hiester ED, Sacks MS. (1998b). Optimal bovine pericardial tissue selection sites. II. Cartographic analysis. J Biomed Mater Res, Vol. 39, No. 2, pp. (215-221).

Huang Lee LLH, Cheung DT, Nimni ME. (1990). Biochemical changes and cytotoxicity associated with the degradation of polymeric glutaraldehyde derived cross-links. $J$ Biomed Mater Res, Vol. 24, No. 9, pp. (1185-1201).

Hudson TW, Zawko S, Deister C, Lundy S, Hu CY, Lee K, Schmidt CE. (2004). Optimized acellular nerve graft is immunologically tolerated and supports regeneration. Tissue Eng, Vol. 10, No. 11-12, pp. (1641-1651).

Ishihara T, Ferans VJ, Jones M, Boyce SW, Roberts WC. (1981). Structure of bovine parietal pericardium and of unimplanted Ionescu shiley pericardial valvular bioprostheses. J Thorac Cardiovasc Surg, Vol. 81, No. 5, pp. (747-757).

Jackson DW, Grood ES, Wilcox P, Butler DL, Simon TM, Holden JP. (1988). The effects of processing techniques on the mechanical properties of bone-anterior cruciate ligament-bone allografts. An experimental study in goats. Am J Sports Med, Vol. 16, No. 2, pp. (101-105).

Jastrzebska M, Zalewska-Rejdak J, Wrzalik R, Kocot A, Mroz I, Barwinski B, Turek A, Cwalina B. (2006). Tannic acid-stabilized pericardium tissue: IR spectroscopy, atomic force microscopy, and dielectric spectroscopy investigations. J Biomed Mater Res A, Vol. 78, No. 1, pp. (148-156).

Jayakrishnan A, Jameela SR. (1996). Glutaraldehyde as a fixative in bioprostheses and drug delivery matrices. Biomaterials, Vol. 17, No. 5, pp. (471-484).

Jee KS, Kim YS, Park KD, Kim YH. (2003). A novel chemical modification of bioprosthetic tissues using L-arginine. Biomaterials, Vol. 24, No. 20, pp. (3409-3416).

Jobling S, Sumpter JP. (1993). Detergent components in sewage effluent are weakly estrogenic to fish - an in vitro study using rainbow-trout. Aquat Toxicol, Vol. 27, pp. (361-372).

Jorge-Herrero E, Fernandez P, Escudero C, Garcia-Paez JM, Castillo-Olivares JL. (1996). Calcification of pericardial tissue pretreated with different amino acids. Biomaterials, Vol. 17, No. 6, pp. (571-575).

Jorge-Herrero E, Fernandez P, Turnay J, Olmo N, Calero P, Garcia R, Freile I, CastilloOlivares JL. (1999). Influence of different chemical cross-linking treatments on the properties of bovine pericardium and collagen. Biomaterials, Vol. 20, No. 6, pp. (539545).

Kasimir MT, Rieder E, Seebacher G, Nigisch A, Dekan B, Wolner E, Weigel G, Simon P. (2006). Decellularization does not eliminate thrombogenicity and inflammatory stimulation in tissue-engineered porcine heart valves. J Heart Valve Dis, Vol. 15, No. 2, pp. (278-286) [discussion 286].

Kasimir MT, Rieder E, Seebacher G, Wolner E, Weigel G, Simon P. (2005). Presence and elimination of the xenoantigen gal (alpha1, 3) gal in tissue-engineered heart valves. Tissue Eng, Vol. 11, No. 7-8, pp. (1274-1280).

Keuren JFW, Wielders SJH, Driessen A, Verhoeven M, Hendriks M, Lindhout T. (2004). Covalently-bound heparin makes collagen thromboresistant. Arterioscler Thromb Vasc Biol, Vol. 24, No. 3, pp. (613-617). 
Lazarou G, Powers K, Pena C, Bruck L, Mikhail MS. (2005). Inflammatory reaction following bovine pericardium graft augmentation for posterior vaginal wall defect repair. Int Urogynecol J Pelvic Floor Dysfunct, Vol. 16, No. 3, pp. (242-244).

Lee C, Kim SH, Choi SH, Kim YJ. (2011) High-concentration glutaraldehyde fixation of bovine pericardium in organic solvent and post-fixation glycine treatment: in vitro material assessment and in vivo anticalcification effect. Eur J Cardiothorac Surg, Vol. 39, No. 3, pp. (381-387).

Lee JM, Boughner DR. (1981). Tissue mechanics of canine pericardium in different test environment. Circ Res, Vol. 49, No. 2, pp. (533-544).

Lee JM, Boughner DR. (1985). Mechanical properties of human pericardium. Differences in viscoelastic response when compared with canine pericardium. Circ Res, Vol. 57, No. 3, pp. (475-481).

Lee WK, Park KD, Han DK, Suh H, Park JC, Kim YH. (2000). Heparinized bovine pericardium as a novel cardiovascular bioprosthesis. Biomaterials, Vol. 21, No. 22, pp. (2323-2330).

Lee WK, Park KD, Kim YH, Suh H, Park JC, Lee JE, Sun K, Baek MJ, Kim HM, Kim SH. (2001). Improved Calcification Resistance and Biocompatibility of Tissue Patch Grafted with Sulfonated PEO or Heparin after Glutaraldehyde Fixation. J Biomed Mater Res, Vol. 58, No. 1, pp. (27-35).

Leukauf C, Szeles C, Salaymeh L, Grimm M, Grabenwoger M, Losert U, Moritz A, Wolner E. (1993). In vitro and in vivo endothelialization of glutaraldehyde treated bovine pericardium. J Heart Valve Dis, Vol. 2, No. 2, pp. (230-235).

Liang HC, Chang Y, Hsu CK, Lee MH, Sung HW. (2004). Effects of crosslinking degree of an acellular biological tissue on its tissue regeneration pattern. Biomaterials, Vol. 25, No. 17, pp. (3541-3552).

Liao J, Joyce EM, Sacks MS. (2008). Effects of decellularization on the mechanical and structural properties of the porcine aortic valve leaflet. Biomaterials, Vol. 29, No. 8, pp. (1065-1074).

Liao J, Yang L, Grashow J, Sacks MS. (2005). Molecular orientation of collagen in intact planar connective tissues under biaxial stretch. Acta Biomater, Vol. 1, No. 1, pp. (4554).

Limpert JN, Desai AR, Kumpf AL, Fallucco MA, Aridge DL. (2009). Repair of abdominal wall defects with bovine pericardium. Am J Surg, Vol. 198, pp. (e60-65).

Love JW. (1997). Cardiac prostheses, In: Principles of tissue engineering, Lanza R, Langer R, Chick W, pp. (365-378), R.G. Landes Company, New York.

Lovekamp JJ, Simionescu DT, Mercuri JJ, Zubiate B, Sacks MS, Vyavahare NR. (2006). Stability and function of glycosaminoglycans in porcine bioprosthetic heart valves. Biomaterials, Vol. 27, No. 8, pp. (1507-1518).

Maestro MM, Turnay J, Olmo N, Fernández P, Suárez D, García Páez JM, Urillo S, Lizarbe MA, Jorge-Herrero E. (2006). Biochemical and mechanical behavior of ostrich pericardium as a new biomaterial. Acta Biomater, Vol. 2, No. 2, pp. (213-219).

Matsagas MI, Bali C, Arnaoutoglou E, Papakostas JC, Nassis C, Papadopoulos G, Kappas AM. (2006). Carotid endarterectomy with bovine pericardium patch angioplasty: mid-term results. Ann Vasc Surg, Vol. 20, No. 5, pp. (614-619).

McFetridge PS, Daniel JW, Bodamyali T, Horrocks M, Chaudhuri JB. (2004). Preparation of porcine carotid arteries for vascular tissue engineering applications. J Biomed Mater Res A, Vol. 70, No. 2, pp. (224-234). 
Menasche P, Flaud P, Huc Co A, Piwnica A. (1984). Collagen vascular grafts: a step towards improved compliance in small-caliber by-pass surgery: preliminary report. Life Support Syst, Vol. 2, No. 4, pp. (233-237).

Mendoza-Novelo B, Avila EE, Cauich-Rodríguez JV, Jorge-Herrero E, Rojo FJ, Guinea GV, Mata-Mata JL. (2011). Decellularization of pericardial tissue and its impact on tensile viscoelasticity and glycosaminoglycan content. Acta Biomater, Vol. 7, No. 3, pp. (1241-1248).

Mendoza-Novelo B, Cauich-Rodriguez JV. (2009). The effect of surfactants, crosslinking agents and L-cysteine on the stabilization and mechanical properties of bovine pericardium. J Appl Biomater Biomech, Vol. 7, No. 2, pp. (123-131).

Meyer SR, Nagendran J, Desai LS, Rayat GR, Churchill TA, Anderson CC, Rajotte RV, Lakey JRT, Ross DB. (2005). Decellularization reduces the immune response to aortic valve allografts in the rat. J Thorac Cardiovasc Surg, Vol. 130, No. 2, pp. (469-476).

Mirsadraee S, Wilcox HE, Korossis S, Kearney JN, Watterson KG, Fisher J, Ingham E. (2006). Development and characterization of an acellular human pericardial matrix. Tissue Eng, Vol. 12, No. 4, pp. (763-773).

Mirsadraee S, Wilcox HE, Watterson KG, Kearney JN, Hunt J, Fisher J, Ingham E. (2007). Biocompatibility of Acellular Human Pericardium. J Surg Res, Vol. 143, No. 2, pp. (407-414).

Moon JJ, West JL. (2008). Vascularization of engineered tissues: approaches to promote angiogenesis in biomaterials. Curr Top Med Chem, Vol. 8, No. 4, pp. (300-310).

Moore MA, Bohachevsky IK, Cheung DT, Boyan BD, Chen W, Bickers RR, McIlroy BK. (1994). Stabilization of pericardial tissue by dye-mediated photooxidation. J Biomed Mater Res, Vol. 28, No. 5, pp. (611-618).

Moritz A, Grimm M, Eybl E, Grabenwoger M, Grabenwoger F, Bock P, Wolner E. (1991). Improved spontaneous endothelialization by postfixation treatment of bovine pericardium. Eur J Cardiothorac Surg, Vol. 5, No. 3, pp. (155-159) [discussion 160].

Neethling WM, Cooper S, Van Den Heever JJ, Hough J, Hodge AJ. (2002). Evaluation of kangaroo pericardium as an alternative substitute for reconstructive cardiac surgery. J Cardiovasc Surg (Torino), Vol. 43, No. 3, pp. (301-306).

Neethling WM, Papadimitriou JM, Swarts E, Hodge AJ. (2000). Kangaroo versus porcine aortic valve tissue-valve geometry morphology, tensile strength and calcification potential. J Cardiovasc Surg (Torino), Vol. 41, No. 3, pp. (341-348).

Nimni ME, Cheung D, Strates B, Kodama M, Sheikh K. (1988). Bioprosthesis derived from cross-linked and chemically modified collagenous tissues, In: Collagen, Vol. III, Nimni ME, pp. (1-38), CRC Press, Boca Raton, FL.

Nogueira GM, Rodas ACD, Weska RF, Aimoli CG, Higa OZ, Maizato M, Leiner AA, Pitombo RNM, Polakiewicz B, Beppu MM. (2010). Bovine pericardium coated with biopolymeric films as an alternative to prevent calcification: In vitro calcification and cytotoxicity results. Materials Science and Engineering C, Vol. 30, pp. (575-582).

Noishiki Y, Kodaira K, Furuse M, Miyata T. (1989). Method of preparing antithrombogenic medical materials, U.S. Patent No. 4,806,595.

Noishiki Y, Miyata T, Kodaira K. (1986). Development of a small caliber vascular graft by a new crosslinking method incorporating slow heparin release collagen and natural tissue compliance. ASAIO Trans, Vol. 32, No. 1, pp. (114-119). 
Ohri R, Hahn SK, Hoffman AS, Stayton PS, Giachelli CM. (2004). Hyaluronic acid grafting mitigates calcification of glutaraldehyde-fixed bovine pericardium. J Biomed Mater Res A, Vol. 70, No. 2, pp. (328-334).

Olde Damink LH, Dijkstra PJ, van Luyn MJ, van Wachem PB, Nieuwenhuis P, Feijen J. (1996). Cross-linking of dermal sheep collagen using a water-soluble carbodiimide. Biomaterials, Vol. 17, No. 8, pp. (765-773).

Pathak CP, Adams AK, Simpson T, Phillips RE, Moore MA. (2004). Treatment of bioprosthetic heart valve tissue with long chain alcohol solution to lower calcification potential. J Biomed Mater Res A, Vol. 69, No. 1, pp. (140-144).

Pereira CA, Lee JM, Haberer S. (1990). Effect of alternative crosslinking methods on the strain rate viscoelastic properties of bovine pericardial bioprosthetic material. J Biomed Mater Res, Vol. 24, No. 3, pp. (345-361).

Petite H, Rault I, Huc A, Menasche P, Herbage D. (1990). Use of the acyl azide method for cross-linking collagen-rich tissues such as pericardium. J Biomed Mater Res, Vol. 24, No. 2, pp. (179-187).

Pierschbacher MD, Ruoslahti E. (1984). Cell attachment activity of fibronectin can be duplicated by small synthetic fragments of the molecule. Nature, Vol. 309, No. 5963, pp. (30-33).

Rieder E, Kasimir MT, Silberhumer G, Seebacher G, Wolner E, Simon P, Weigel G. (2004). Decellularization protocols of porcine heart valves differ importantly in efficiency of cell removal and susceptibility of the matrix to recellularization with human vascular cells. J Thorac Cardiovasc Surg, Vol. 127, No. 2, pp. (399-405).

Roberts TS, Drez Jr D, McCarthy W, Paine R. (1991). Anterior cruciate ligament reconstruction using freeze-dried, ethylene oxide-sterilized, bone-patellar tendonbone allografts. Two year results in thirty-six patients. Am J Sports Med, Vol. 19, No. 1 , pp. (35-41).

Rosenberg D. (1978). Dialdehyde starch tanned bovine heterografts: Development, In: Vascular grafts, Sawyer PN, Kaplitt MJ, pp. (261-270), Appleton Century-Crofts, New York.

Ruoslahti E, Pierschbacher MD. (1987). New perspectives in cell adhesion: RGD and integrins. Science, Vol. 238, No. 4826, pp. (491-497).

Sacks MS. (2003). Incorporation of experimentally-derived fiber orientation into a structural constitutive model for planar collagenous tissues. J Biomech Eng, Vol. 125, No. 2, pp. (280-287).

Santibáñez-Salgado JA, Olmos-Zúñiga JR, Pérez-López M, Aboitiz-Rivera C, GaxiolaGaxiola M, Jasso-Victoria R, Sotres-Vega A, Baltazares-Lipp M, Pérez-Covarrubias D, Villalba-Caloca J. (2010). Lyophilized Glutaraldehyde-Preserved Bovine Pericardium for Experimental Atrial Septal Defect Closure. Eur Cell Mater, Vol. 19, pp. (158-165).

Sato H, Suzuki N, Baba T, Ueda T, Mawatari T, Izumiyama O, Morishita K, Hasegawa T. (2008). Repair of ventricular septal perforation with asymmetrical conical patch exclusion. Ann Thorac Cardiovasc Surg, Vol. 14, No. 3, pp. (192-195).

Schenke-Layland K, Vasilevski O, Opitz F, Konig K, Riemann I, Halbhuber KJ, Wahlers T, Stock UA. (2003). Impact of decellularization of xenogeneic tissue on extracellular matrix integrity for tissue engineering of heart valves. J Struct Biol, Vol. 143, No. 3, pp. (201-208). 
Schmidt CE, Baier JM. (2000). Acellular vascular tissues: natural biomaterials for tissue repair and tissue engineering. Biomaterials, Vol. 21, No. 22, pp. (2215-2231).

Schoen FJ, Levy RJ. (1999). Tissue heart valves: current challenges and future research perspectives. J Biomed Mater Res, Vol. 47, No. 4, pp. (439-465).

Simon P, Kasimir MT, Rieder E, Weigel G. (2006). Tissue Engineering of heart valvesImmunologic and inflammatory challenges of the allograft scaffold. Progress in Pediatric Cardiology, Vol. 21, pp. (161-165).

Simon P, Kasimir MT, Seebacher G, Weigel G, Ullrich R, Salzer-Muhar U, Rieder E, Wolner E. (2003). Early failure of the tissue engineered porcine heart valve SYNERGRAFT in pediatric patients. Eur J Cardiothorac Surg, Vol. 23, No. 6, pp. (1002-1006) [discussion 1006].

Sommers KE, David TE. (1997). Aortic valve replacement with patch enlargement of the aortic annulus. Ann Thorac Surg, Vol. 63, No. 6, pp. (1608-1612).

Soto AM, Justicia H, Wray JM, Sonnenschein C. (1991). P-nonylphenol, an estrogenic xenobiotic released from modified polystyrene. Environ Health Perspect, Vol. 92, pp. (167-173).

Sung HW, Chang WH, Ma CY, Lee MH. (2003). Crosslinking of biological tissues using genipin and/or carbodiimide. J Biomed Mater Res A, Vol. 64, No. 3, pp. (427-438).

Sung HW, Hsu CS, Wang SP, Hsu HL. (1997). Degradation potential of biological tissues fixed with various fixatives: An in vitro study. J Biomed Mater Res, Vol. 35, No. 2, pp. (147-155).

Sung HW, Huang RN, Huang LLH, Tsai CC. (1999). In vitro evaluation of cytotoxicity of a naturally occurring crosslinking reagent for biological tissue fixation. J Biomater Sci Polymer, Vol. 10, pp. (63-78).

Taylor PM, Cass AEG, Yacoub MH. (2006). Extracellular matrix scaffolds for tissue engineering heart valves. Progress in Pediatric Cardiology, Vol. 21, pp. (219-225).

Tedder ME, Liao J, Weed B, Stabler C, Zhang H, Simionescu A, Simionescu DT. (2009). Stabilized Collagen Scaffolds for Heart Valve Tissue Engineering. Tissue Eng Part A, Vol. 15, No. 6, pp. (1257-1268).

Teebken OE, Bader A, Steinhoff G, Haverich A. (2000). Tissue engineering of vascular grafts: human cell seeding of decellularised porcine matrix. Eur J Vasc Endovasc Surg, Vol. 19, No. 4, pp. (381-386).

Thubrikar MJ, Deck JD, Aouad J, Nolan SP. (1983). Role of mechanical stress in calcification of aortic bioprosthetic valves. J Thorac Cardiovasc Surg, Vol. 86, No. 1, pp. (115-125).

Thyagarajan K, Nguyen H, Tu R, Lohre J, Guida S, Sagartz JW, Quijano RC. (1992). Preliminary evaluation of calcification potential of Denacolt treated small diameter biological vascular grafts. Trans Soc Biomater, Vol. 15, pp. (686-688).

Timkovich R. (1977). Detection of the stable addition of carbodiimide to proteins. Anal Biochem, Vol. 79, No. 1-2, pp. (135-143).

Trantina-Yates AE, Human P, Zilla P. (2003). Detoxification on top of enhanced, diamineextended glutaraldehyde fixation significantly reduces bioprosthetic root calcification in the sheep model. J Heart Valve Dis, Vol. 12, No. 1, pp. (93-101) [discussion 100-1].

Tsai TH, Westly J, Lee TF, Chen CF. (1994). Identification and determination of geniposide, genipin, gardenoside, and geniposidic acid from herbs by HPLC/photodiode-array detection. J Liq Chromatography, Vol. 17, pp. (2199-2205). 
Ueda Y, TorrianniMW, Coppin CM, Iwai S, Sawa Y, Matsuda H. (2006). Antigen clearing from porcine heart valves with preservation of structural integrity. Int J Artif Organs, Vol. 29, No. 8, pp. (781-789).

Vesely I, Boughner D, Song T. (1988). Tissue buckling as a mechanism of bioprosthetic valve failure. Ann Thorac Surg, Vol. 46, No. 3, pp. (302-308).

Vesely I, Noseworthy R, Pringle G. (1995). The hybrid xenograft/autograft bioprosthetic heart valve: in vivo evaluation of tissue extraction. Ann Thorac Surg, Vol. 60, No. Suppl. 2, pp. (S359-364).

Vesely I. (2005). Heart Valve Tissue Engineering. Circ Res, Vol. 97, No. 8, pp. (743-755).

Vyavahare N, Hirsch D, Lerner E, Baskin JZ, Schoen FJ, Bianco R, Kruth HS, Zand R, Levy RJ. (1997). Prevention of bioprosthetic heart valve calcification by ethanol preincubation. Efficacy and mechanisms. Circulation, Vol. 95, No. 2, pp. (479-488).

Vyavahare NR, Hirsch D, Lerner E, Baskin JZ, Zand R, Schoen FJ, Levy RJ. (1998). Prevention of calcification of glutaraldehyde-crosslinked porcine aortic cusps by ethanol preincubation: Mechanistic studies of protein structure and waterbiomaterial relationships. J Biomed Mater Res, Vol. 40, No. 4, pp. (577-585).

Wang D, Jiang H, Li J, Zhou JY, Hu SS. (2008). Mitigated calcification of glutaraldehydefixed bovine pericardium by tannic acid in rats. Chin Med J (Engl), Vol. 121, No. 17, pp. (1675-1679).

Wei HJ, Liang HC, Lee MH, Huang YC, Chang Y, Sung HW. (2005). Construction of varying porous structures in acellular bovine pericardia as a tissue-engineering extracellular matrix. Biomaterials, Vol. 26, No. 14, pp. (1905-1913).

Wiegner AW, Bing OH, Borg TK, Caulfield JB. (1981). Mechanical and structural of canine pericardium. Circ Res, Vol. 49, No. 3, pp. (807-814).

Woods T, Gratzer PF. (2005). Effectiveness of three extraction techniques in the development of a decellularized bone-anterior cruciate ligament-bone graft. Biomaterials, Vol. 26, No. 35, pp. (7339-7349).

Yamamoto H, Yamamoto F, Ishibashi K, Motokawa M. (2009). In situ replacement with equine pericardial roll grafts for ruptured infected aneurysms of the abdominal aorta. J Vasc Surg, Vol. 49, No. 4, pp. (1041-1045).

Yoshioka SA, Goissis G. (2008). Thermal and spectrophotometric studies of new crosslinking method for collagen matrix with glutaraldehyde acetals. J Mater Sci Mater Med, Vol. 19, No. 3, pp. (1215-1223).

Zhou J, Fritze O, Schleicher M, Wendel HP, Schenke-Layland K, Harasztosi C, Hu S, Stock UA. (2010). Impact of heart valve decellularization on 3-D ultrastructure, immunogenicity and thrombogenicity. Biomaterials, Vol. 31, No. 9, pp. (2549-2554).

Zilla P, Weissenstein C, Human P, Dower T, von Oppell UO. (2000). High glutaraldehyde concentrations mitigate bioprosthetic root calcification in the sheep model. Ann Thorac Surg, Vol. 70, No. 6, pp. (2091-2095).

Zioupos P, Barbenel JC. (1994). Mechanics of native bovine pericardium. I. The multiangular behavior of strength and stiffness of the tissue. Biomaterials, Vol. 15, No. 5, pp. (366373). 


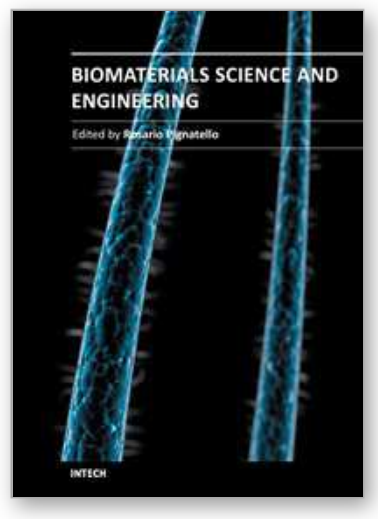

\author{
Biomaterials Science and Engineering \\ Edited by Prof. Rosario Pignatello
}

ISBN 978-953-307-609-6

Hard cover, 456 pages

Publisher InTech

Published online 15, September, 2011

Published in print edition September, 2011

These contribution books collect reviews and original articles from eminent experts working in the interdisciplinary arena of biomaterial development and use. From their direct and recent experience, the readers can achieve a wide vision on the new and ongoing potentials of different synthetic and engineered biomaterials. Contributions were not selected based on a direct market or clinical interest, than on results coming from very fundamental studies which have been mainly gathered for this book. This fact will also allow to gain a more general view of what and how the various biomaterials can do and work for, along with the methodologies necessary to design, develop and characterize them, without the restrictions necessarily imposed by industrial or profit concerns. The book collects 22 chapters related to recent researches on new materials, particularly dealing with their potential and different applications in biomedicine and clinics: from tissue engineering to polymeric scaffolds, from bone mimetic products to prostheses, up to strategies to manage their interaction with living cells.

\title{
How to reference
}

In order to correctly reference this scholarly work, feel free to copy and paste the following:

Escande Rémi, Nizar Khelil, Isabelle Di Centa, Caroline Roques, Maguette Ba, Fatima Medjahed-Hamidi, Frederic Chaubet, Didier Letourneur, Emmanuel Lansac and Anne Meddahi-Pelle (2011). Pericardial Processing: Challenges, Outcomes and Future Prospects, Biomaterials Science and Engineering, Prof. Rosario Pignatello (Ed.), ISBN: 978-953-307-609-6, InTech, Available from: http://www.intechopen.com/books/biomaterials-science-and-engineering/pericardial-processing-challengesoutcomes-and-future-prospects

\section{INTECH}

open science | open minds

\section{InTech Europe}

University Campus STeP Ri Slavka Krautzeka 83/A

51000 Rijeka, Croatia Phone: +385 (51) 770447

Fax: +385 (51) 686166

www.intechopen.com

\section{InTech China}

Unit 405, Office Block, Hotel Equatorial Shanghai

No.65, Yan An Road (West), Shanghai, 200040, China

中国上海市延安西路65号上海国际贵都大饭店办公楼405单元

Phone: +86-21-62489820

Fax: +86-21-62489821 
(C) 2011 The Author(s). Licensee IntechOpen. This chapter is distributed under the terms of the Creative Commons Attribution-NonCommercialShareAlike-3.0 License, which permits use, distribution and reproduction for non-commercial purposes, provided the original is properly cited and derivative works building on this content are distributed under the same license. 